\title{
An Exploration On The Differences In Emotional Intelligence Of First Year Students Examined Across Disciplines Within The School Of Business In A Liberal Arts College
}

Karen K. Yarrish, Keystone College, USA

Mark D. Law, Bloomsburg University, USA

\begin{abstract}
In preparing the next generation of business professionals, educators need to take seriously the responsibility of empowering students with tools to assist them in their pursuits. One area of interest is Emotional Intelligence. Emotional Intelligence determines how students exercise selfcontrol, zeal and persistence, and the ability to motivate themselves. The purpose of the study is two-fold with respect to Emotional Intelligence. First, the researchers will explore the differences of emotional intelligence examined by students' discipline within the school of business in a liberal arts college. Secondly, the researchers will analyze the implications for educators, administrators, researchers, and other interested parties. Findings, conclusions, and recommendations will be presented.
\end{abstract}

Keywords: Emotional Intelligence, College Students, Business Major, Emotions

\section{INTRODUCTION}

$\mathrm{n}$ preparing the next generation of business and management professionals, educators need to take seriously the responsibility of empowering them with tools to assist them in their pursuits. One area of interest is emotional intelligence. According to Nelson and Low (2003) emotional intelligence is the single most important influencing variable in personal achievement, career success, leadership, and life satisfaction.

Business and management professionals will be confronted with many compelling challenges over the next decade and will witness accelerated changes that have never been seen before in the industry. These impending changes need to be examined by educators and researchers in the fields of education, business, and management in an effort to better prepare successful business and management professionals.

\section{PURPOSE}

The purpose of the study was to explore the differences of emotional intelligence examined by discipline in first year students in the school of business in a liberal arts college.

\section{LITERATURE REVIEW}

Emotional intelligence determines how people exercise self-control, zeal and persistence, and the ability to motivate themselves (Goleman, 1995). However; current information must be gathered to facilitate the practices and needs of business and management professionals. One important management skill related to emotional 
intelligence is conflict management. Conflict management may be more closely related to emotional intelligence than to IQ. Lacking empathy, seeing the other persons perspective, may contribute to the problem of conflict rather than helping to resolve conflict (Stuller, 1998). Emotional intelligence can have an impact on the ability to attain jobs. Interns with higher levels of emotional intelligence were hired over those with lower scores in emotional intelligence (Maynard, 2003). Gender does not appear to be a determining factor in emotional intelligence. Both males and females have scored very high in emotional intelligence and those who do may have been promoted more quickly (Petrides, Furnham, \& Martin, 2004).

Historically intelligence has been measured by tests that result in a number. It has been assumed that the higher the number, the greater the intelligence of the person (Johnson, 2006). Arguably there have been many successful people who weren't at the top of their class or even close to being A students (Scott, 2007). So what other contributing factors have lead to the attainment of success in these individuals? One possibility is a high level of emotional intelligence.

Salovey and Mayer (1990) were the first to use Emotional intelligence. They defined it as individual's ability to monitor their own and others' feelings and emotions, to discriminate among emotions, and to use this information to guide thinking and action. Later Goleman (1995) defined emotional intelligence as the ability to recognize and understand emotions and the skill to use this awareness to manage self and the relationships with others. According to Goleman (1995) emotional intelligence consists of five components including, knowing one's emotions, managing emotions, motivating oneself, recognizing emotions in other people, and handling relationships.

1. Knowing one's emotions consists of self-awareness or recognizing a feeling as it happens. The ability to do so is crucial to insight and self-understanding.

2. Managing emotions involves handling feelings so they are appropriate. Soothing oneself, shaking off anxiety, gloom, or irritability are examples of managing emotions.

3. Motivating oneself includes rallying emotions in the service of a goal. Delayed gratification and stifling impulsiveness underlie accomplishments.

4. Recognizing emotions in others describes the ability to empathize with others. Empathy builds on emotional self-awareness, and is a fundamental people skill.

5. Handling relationships is managing emotions in others. These are the abilities that lead to popularity, leadership, and interpersonal effectiveness (Goleman, 1995).

The literature on emotional intelligence attempts to link emotional intelligence to other constructs such as leadership and performance. Dulewicz and Higgs (2000) showed that emotional intelligence was predictive of the career success of 100 managers and Chan (2007) linked emotional intelligence as important to leadership. Law, Wong, and Song (2004) showed that emotional intelligence is conceptually distinct from personality.

In order to determine how to teach and what classes to make available, the researchers of this study sought to examine to what extent there are differences in understanding self emotion, understanding others emotions, the use of emotion, and regulation of emotion and how these relate to a student's discipline. This project will seek to add to the existing body of knowledge of business and management theory and disseminate the results to teachers, administrators, researchers, and other interested parties.

\section{RESEARCH QUESTIONS AND VARIABLES}

Research Question 1: To what extent are the differences in self-emotions related to a student's discipline?

Research Question 2: To what extent are the differences in others-emotions related to a student's discipline?

Research Question 3: To what extent are the differences in use of emotion related to a student's discipline?

Research Question 4: To what extent are the differences in regulation of emotion related to a student's discipline?

\section{PARTICIPANTS}

In the study, 66 first year students in the business division of a small liberal arts college took the survey in Fall, 2008. Seventeen students were majoring in culinary arts, ten majored in business, fourteen were sport and 
recreation management majors, fifteen were majoring in information technology and ten students were from the major of accounting. Their ages ranged from 18 to 24 . Forty eight of the participants were male and eighteen were female.

\section{INSTRUMENT}

The survey instrument was generated, tested and cross validated through a rigorous development process. The process started with three groups of MBA and undergraduate students trained on the Emotional Intelligence construct generating items according to the four-dimensional definition of emotional intelligence as proposed by Davies, Stankov, \& Roberts (1998). Inappropriate items were deleted according to three criteria, resulting in a total of 9 items for each dimension. Items were further eliminated on the basis of their factor loadings on their respective factors as well as their correlation's with selected criterion variables using a sample of 189 university students. Sixteen items (four items per dimension) were selected as a result. This 16 item scale was cross-validated with three additional student samples, 116 non-teaching employees from a university, and 149 supervisor-subordinate dyads. The entire development process is described in Wong, Law, and Song (2002) in detail.

\section{PROCEDURE}

Surveys were distributed to students taking an introductory course (IDS 101) in the school of business of a small liberal arts college. Each survey included one self-rating questionnaire completed voluntarily by the students. The survey measured each student's own level of emotional intelligence (EI) in four different areas; self emotion, others-emotions, use of emotion, and regulation of emotion. The survey took approximately ten minutes to complete. The researcher collected the completed surveys and placed them in a sealed envelope. Anonymity was maintained by assigning students a code number. The surveys were tabulated and the relevant item responses scored on the four scales of emotional intelligence.

\section{FINDINGS}

\section{Research Question 1: To what extent are the differences in self-emotions related to a student's discipline?}

In order to answer the research question one, four survey items were used to gain an understanding on the variation of self-emotions appraisal when examined across the five disciplines in the college of business. In order to observe the self-emotions appraisal, the means of the four survey items were totaled and compared by discipline. With this population the data revealed slight differences based on discipline with respect to self-emotions appraisal with a standard deviation of .13. Culinary arts students rated the highest at 4.21 and accounting students rated the lowest at 3.88 as illustrated in Table 1 .

Table 1

Self-Emotions Appraisal Examined by Major

\begin{tabular}{|c|c|c|c|c|c|c|}
\hline \multirow[b]{2}{*}{ Self-Emotions Appraisal } & \multicolumn{6}{|c|}{ Mean By Major } \\
\hline & $\mathrm{n}$ & Acct & Bus & CulArts & IT & Sports \\
\hline $\begin{array}{l}\text { I have a good sense of why I have } \\
\text { certain feelings most of the time. }\end{array}$ & 66 & 4.10 & 3.93 & 4.14 & 3.93 & 4.07 \\
\hline $\begin{array}{l}\text { I have good understanding of my } \\
\text { own emotions. }\end{array}$ & 66 & 4.10 & 3.93 & 4.36 & 3.79 & 3.93 \\
\hline I really understand what I feel. & 66 & 3.50 & 3.57 & 4.14 & 3.86 & 4.07 \\
\hline $\begin{array}{l}\text { I always know whether or not I am } \\
\text { happy. }\end{array}$ & 66 & 3.80 & 4.43 & 4.21 & 4.07 & 4.07 \\
\hline Total self-emotions appraisal & 66 & 3.88 & 3.97 & 4.21 & 3.91 & 4.04 \\
\hline
\end{tabular}

Note. Application Scale: $1=$ Never; $2=$ Seldom; $3=$ Sometimes; $4=$ Most Times; $5=$ Always 


\section{Research Question 2: To what extent are the differences in others-emotions related to a student's discipline?}

In order to answer research question two, four survey items were used to gain an understanding on the variation of other-emotions appraisal when examined across the five disciplines in the college of business. In order to observe the other-emotions appraisal, the means of the four survey items were totaled and compared by discipline. With this population the data revealed differences based on discipline with respect to other-emotions appraisal with a standard deviation of .19. Culinary arts students rated the highest at 3.84 and information technology students rated the lowest at 3.40 as illustrated in Table 2.

Table 2

Others-Emotions Appraisal Examined by Major

\begin{tabular}{|c|c|c|c|c|c|c|}
\hline \multirow[b]{2}{*}{ Others-Emotions Appraisal } & \multicolumn{6}{|c|}{ Mean By Major } \\
\hline & $\mathrm{n}$ & Acct & Bus & CulArts & IT & Sports \\
\hline $\begin{array}{l}\text { I always know my friends' } \\
\text { emotions from their behavior. }\end{array}$ & 66 & 3.60 & 3.50 & 3.86 & 3.36 & 3.50 \\
\hline $\begin{array}{l}\text { I am a good observer of others' } \\
\text { emotions. }\end{array}$ & 66 & 3.60 & 3.79 & 4.14 & 3.50 & 3.57 \\
\hline $\begin{array}{l}\text { I am sensitive to the feelings and } \\
\text { emotions of others. }\end{array}$ & 66 & 3.90 & 3.57 & 3.71 & 3.43 & 3.29 \\
\hline $\begin{array}{l}\text { I have good understanding of the } \\
\text { emotions of people around me. }\end{array}$ & 66 & 3.60 & 3.57 & 3.64 & 3.29 & 3.21 \\
\hline Total others-emotions appraisal & 66 & 3.68 & 3.61 & 3.84 & 3.40 & 3.39 \\
\hline
\end{tabular}

Note. Application Scale: 1 = Never; 2 = Seldom; 3 = Sometimes; 4 = Most Times; $5=$ Always

\section{Research Question 3: To what extent are the differences in use of emotion related to a student's discipline?}

In order to answer research question three, four survey items were used to gain an understanding on the variation of use of emotion appraisal when examined across the five disciplines in the college of business. In order to observe the use of emotion appraisal, the means of the four survey items were totaled and compared by discipline. With this population the data revealed differences based on discipline with respect to use of emotion appraisal with a standard deviation of .16. Sports and recreation management students rated the highest at 4.02 and business students rated the lowest at 3.66 as illustrated in Table 3.

Table 3

Use of Emotion Examined by Major

\begin{tabular}{|c|c|c|c|c|c|c|}
\hline \multirow[b]{2}{*}{ Use of Emotion } & \multicolumn{6}{|c|}{ Mean By Major } \\
\hline & $\mathrm{n}$ & Acct & Bus & CulArts & IT & Sports \\
\hline $\begin{array}{l}\text { I always set goals for myself and } \\
\text { then try my best to achieve them. }\end{array}$ & 66 & 4.20 & 3.50 & 3.71 & 3.50 & 4.14 \\
\hline $\begin{array}{l}\text { I always tell myself I am a } \\
\text { competent person. }\end{array}$ & 66 & 3.50 & 3.57 & 3.71 & 3.43 & 3.71 \\
\hline I am a self-motivating person. & 66 & 3.70 & 3.71 & 4.00 & 3.79 & 4.00 \\
\hline $\begin{array}{l}\text { I would always encourage myself to } \\
\text { try my best. }\end{array}$ & 66 & 4.30 & 3.86 & 4.29 & 4.00 & 4.21 \\
\hline Total use of emotion & 66 & 3.93 & 3.66 & 3.93 & 3.68 & 4.02 \\
\hline
\end{tabular}

Note. Application Scale: 1 = Never; 2 = Seldom; $3=$ Sometimes; $4=$ Most Times; $5=$ Always 
Research Question 4: To what extent are the differences in regulation of emotion related to a student's discipline?

In order to answer research question four, four survey items were used to gain an understanding on the variation of regulation of emotion appraisal when examined across the five disciplines in the college of business. In order to observe the regulation of emotion appraisal, the means of the four survey items were totaled and compared by discipline. With this population the data revealed differences based on discipline with respect to regulation of emotion appraisal with a standard deviation of .15. Accounting students rated the highest at 3.78 and information technology students rated the lowest at 3.38 as illustrated in Table 4.

Table 4

Regulation of Emotion Examined by Major

\begin{tabular}{|c|c|c|c|c|c|c|}
\hline \multirow[b]{2}{*}{ Regulation of Emotion } & \multicolumn{6}{|c|}{ Mean By Major } \\
\hline & $\mathrm{n}$ & Acct & Bus & CulArts & IT & Sports \\
\hline $\begin{array}{l}\text { I am able to control my temper so } \\
\text { that I can handle difficulties }\end{array}$ & 66 & 3.80 & 3.50 & 3.71 & 3.29 & 3.57 \\
\hline $\begin{array}{l}\text { I am quite capable of controlling } \\
\text { my own emotions. }\end{array}$ & 66 & 3.80 & 3.86 & 3.86 & 3.64 & 3.79 \\
\hline $\begin{array}{l}\text { I can always calm down quickly } \\
\text { when I am very angry. }\end{array}$ & 66 & 3.40 & 3.57 & 3.21 & 3.07 & 3.36 \\
\hline $\begin{array}{l}\text { I have good control of my own } \\
\text { emotions. }\end{array}$ & 66 & 4.10 & 3.86 & 3.86 & 3.50 & 3.86 \\
\hline Total regulation of emotion & 66 & 3.78 & 3.70 & 3.66 & 3.38 & 3.65 \\
\hline
\end{tabular}

Note. Application Scale: 1 = Never; 2 = Seldom; $3=$ Sometimes; $4=$ Most Times; $5=$ Always

\section{CONCLUSION}

There is an increase in demand for the primary schools up to the college and university level to develop emotional and social growth in students (Goleman 1995 \& Liff, 2003). This study explored the differences of emotional intelligence examined by discipline in first year students in the school of business in a liberal arts college. Within this population, the data exemplified that there are differences related to self-emotions appraisal, otheremotions appraisal, use of emotion appraisal, and regulation of emotion appraisal when examined by discipline. While the population of this studied was limited, the results showed that students are in need of an increased emotional intelligence development in all areas. However, the results of the study showed that improvement is needed in certain areas of emotional intelligence for students within certain disciplines, as differentiated in the analysis of the four proceeding tables of emotional intelligence.

\section{RECOMMENDATIONS}

The focus of this study was to explore the differences of emotional intelligence examined by discipline in first year students in the school of business in a liberal arts college. One of the limitations of the study was the fact the study's parameters were limited to first year students in the school of business at a liberal arts college. It would be interesting to see how the differences in emotional intelligence vary with all students in the college of business at both private and public colleges and universities, in other geographical regions of the country and/or other schools of study in both colleges and universities. With this said, the authors recommend a replicate study comparing all students in the college of business at either a college or university in the United States. 


\section{AUTHOR INFORMATION}

Karen Yarrish is an Associate Professor of Business at Keystone College. She received her Ph.D. from the Pennsylvania State University and is a certified Senior Professional in Human Resources (SPHR). She held the professional position of director of human resources prior to moving into academia. Her research interests include the areas of performance management, leadership, and emotional intelligence.

Dr. Mark Law is an Associate Professor of Accounting at Bloomsburg University of Pennsylvania. He received his $\mathrm{Ph} . \mathrm{D}$. from the Pennsylvania State University and is a licensed Certified Public Accountant. His career began in public accounting as a staff accountant before he established and developed an accounting and computer consulting practice prior to moving into academia. His research interests include the areas of accounting information systems, construction technology, and emotional intelligence.

\section{REFERENCES}

1. Chan, D. W., (2007). Leadership competencies among Chinese gifted students in Hong Kong: The connection with emotional intelligence and successful intelligence. Roeper Review, Vol 29(3), 183-189.

2. Davies, M., Stankov, L., \& Roberts, R. D. (1998). Emotional intelligence: In search of an elusive construct. Journal of Personality and Social Psychology, 75, 989-1015.

3. Dulewicz, V., \& Higgs, M. (2000). Emotional intelligence: A review and evaluation study. Journal of Managerial Psychology, 15(4), 341-372.

4. Goleman, D. (1995). Emotional intelligence. New York: Bantam.

5. Johnson, A. Encounter, (2006). Vol 19, Issue 4, p 40-46.

6. Law, K. S., Wong, C., \& Song, L. J. (2004). The construct and criterion validity of emotional intelligence and its potential utility for management studies. Journal of Applied Psychology vol 89 No 3, 483-496.

7. Liff, S. B. (2003). Social and emotional intelligence: Applications for developmental education. Journal of Developmental Education, 26(3), 28-32.

8. Maynard, M. L. (2003). Emotional intelligence and perceived employability for internship curriculum. Psychological Reports 93, p 791-792.

9. Nelson, D. \& Low, G. (2003). Emotional intelligence: Achieving academic and career excellence. Upper Saddle River, New Jersey: Prentice Hall.

10. Petrides, K. V., Furnham, A. \& Martin, G. N. (2004). Estimates of emotional and psychometric intelligence. Journal of Social Psychology, 144, p 149-162.

11. Salovey, P. \& Mayer, J. D. (1990). Emotional intelligence. Imagination, Cognition and Personality. 9, 185-211.

12. Stuller, J. (1998). Unconventional smarts. Across the Board 35, p 22-23.

13. Scott, S. Do grades really matter? Maclean's (2007). Vol 120, Issue 35/36, p 70-74.

14. Wong, C. S., \& Law, K. S. (2002). The effects of leader and follower emotional intelligence on performance and attitude: An exploratory study. The Leadership Quarterly, 13, 243-274. 